\title{
Effects of copper on the physiological responses of the commercial crab Lithodes santolla (Decapoda: Anomura) larvae
}

\author{
OSCAR ANTONIO AMIN and LAURA INÉS COMOGLIO \\ Centro Austral de Investigaciones Científicas (CADIC - CONICET), B. Houssay 200 (V9410BFD), Ushuaia, \\ Tierra del Fuego, Argentina. E-mail: oamin@cadic.gov.ar
}

\begin{abstract}
SUMMARY: Effects of copper toxicity on zoea I of Lithodes santolla (Decapoda: Anomura) were analysed. The 96-h $\mathrm{LC}_{50}$ was estimated, resulting in $298.5 \mu \mathrm{g} \mathrm{L} \mathrm{L}^{-1}$. Groups of larvae were exposed to sublethal concentrations $\left(40,80\right.$ and $\left.160 \mu \mathrm{g} \mathrm{L} \mathrm{L}^{-1}\right)$ for $96 \mathrm{~h}$. Oxygen consumption, ammonia excretion, $\mathrm{O}: \mathrm{N}$ atomic ratio, lipid peroxidation (LPO) and body water content were measured. Oxygen consumption of treated groups (mean $46.92 \pm 8.03 \mu \mathrm{g}$-atom $\mathrm{O}_{2} \mathrm{~h}^{-1} \mathrm{mg}^{-1}$ ) did not differ significantly with control. Ammonia excretion decreased by $60 \%$ at higher $\mathrm{Cu}$ concentration $\left(1.61^{2} \pm 0.65 \mu \mathrm{g}\right.$-atom $\left.\mathrm{N}-\mathrm{NH}_{3} \mathrm{~h}^{-1} \mathrm{mg}^{-1}\right)$, leading to a $117 \%$ increase in the O:N ratio. LPO values during the exposure time were higher in all treatments than in the controls. The water content was significantly higher in treatments than in controls. The highest concentration assayed, which represents about $50 \%$ of $96-\mathrm{h} \mathrm{LC} \mathrm{L}_{50}$, had evident effects on the parameters analysed. The values of copper in water reported for the coastal zone of Ushuaia bay exceed the value established by the United States Environmental Protection Agency (USEPA) for ambient water quality criteria. Therefore, the results obtained in the present study are a contribution to the study of potential effects of copper as a common stressor in the first larval stage of this commercial species of the Beagle Channel.
\end{abstract}

Keywords: crustacean larvae, oxygen consumption, ammonia excretion, O:N atomic ratio, lipid peroxidation, copper.

RESUMEN: IMPACTO DEL COBRE SOBRE LAS RESPUESTAS FISIOLÓGICAS DE LA LARVA DEL CANGREJO COMERCIAL LITHODES SANTOlla (DeCÁPODA: Anomura). - Los efectos de la toxicidad del cobre sobre la zoea I de Lithodes santolla (Decapoda: Anomura) fueron analizados. La CL50 96-h fue estimada en 298,5 $\mathrm{\mu g} \mathrm{L}{ }^{-1}$. Grupos de larvas fueron expuestos a concentraciones subletales (40; 80 y $160 \mu \mathrm{g} \mathrm{L}^{-1}$ ) durante 96 horas. El consumo de oxígeno, excreción de amonio, relación atómica O:N, lipoperoxidación (LPO) y contenido de agua corporal fueron medidos. El consumo de oxígeno de los grupos tratados (media $46.92 \pm 8.03 \mu \mathrm{g}$-átomo $\left.\mathrm{O}_{2} \mathrm{~h}^{-1} \mathrm{mg}^{-1}\right)$ no difirió significativamente del control. La excreción de amonio disminuyó un $60 \%$ en la mayor concentración de $\mathrm{Cu}\left(1.61 \pm 0.65 \mu \mathrm{g}\right.$-átomo $\left.\mathrm{N}_{-} \mathrm{NH}_{3} \mathrm{~h}^{-1} \mathrm{mg}^{-1}\right)$ produciendo un incremento del $117 \%$ en la tasa O:N. Los valores de LPO a lo largo de la exposición fueron mayores en todos los tratamientos respecto al control. El contenido de agua corporal fue mayor en los tratamientos que en el control. La mayor concentración ensayada, que representa alrededor del 50\% de la CL50 96-h estimada produjo efectos evidentes sobre los parámetros analizados. Los valores de cobre en agua reportados para la zona costera de bahía Ushuaia exceden los establecidos por la Agencia de Protección Ambiental de Estados Unidos (USEPA) como criterio de calidad ambiental. Por esta razón, los resultados obtenidos en el presente estudio se convierten en una contribución sobre el impacto potencial del cobre como un estresor común durante el primer estadio larval de esta importante especie comercial del Canal Beagle.

Palabras clave: larva de crustáceos, consumo de oxígeno, excreción de amonio, relación atómica O:N, lipoperoxidación, cobre.

\section{INTRODUCTION}

Heavy metals have been described as very dangerous pollutants for several aquatic species. Among them, copper is an essential metal which is a widespread contaminant and its anthropogenic input can occur from a variety of sources (Marcovecchio, 2000). The copper concentration in marine water 
varies within a broad range, from $0.05 \mu \mathrm{g} \mathrm{L}^{-1}$ in unpolluted marine waters to $810-1000 \mu \mathrm{g} \mathrm{L}^{-1}$ in highly polluted areas (Soegianto et al., 1999). In spite of its properties as an essential metal for crustaceans, copper can alter metabolic processes (Fingerman et al., 1996; Zapata et al., 2001; Espina and Vanegas Perez, 2006), including those related to aerobic metabolism and oxidative stress (Geracitano et al., 2002). Studies have shown that metals such as copper exhibit the ability to produce reactive oxygen species, resulting in lipid peroxidation, DNA damage, depletion of sulfhydryls, and altered calcium homeostasis (Stohs and Bagchi, 1995; Barata et al., 2005). Sensitivity to copper can also depend on the homeostatic regulation of its uptake, storage and excretion (Depledge and Rainbow, 1990), regulation of membrane permeability and the amount of permeable membrane to body size through which copper can be absorbed (Newman and Heagler, 1991).

High concentrations of metals have been measured in coastal waters of Ushuaia Bay $\left(54^{\circ} 48^{\prime} \mathrm{S}, 68^{\circ} 19^{\prime} \mathrm{W}\right.$, Beagle Channel), mainly from urban effluents, industrial waste and the intensive maritime traffic in the local port, with copper reaching a peak level of $60.68 \mu \mathrm{g} \mathrm{L}^{-1}$ (Amin et al., 1997). The southern king crab, Lithodes santolla (Molina, 1872) is the most important shellfish currently exploited commercially in the Beagle Channel. Shallow waters like bays have been mentioned as a possible recruitment area (Lovrich, 1997). Since larvae begin to moult to zoea II on the fifth to sixth day after hatching (Comoglio and Vinuesa, 1991), bioassays are always conducted within $96 \mathrm{~h}$ of exposure. This study, carried out under semi-static conditions, as previously done for other metals by Amin et al. (1998, 2003), attempts to evaluate the effects of copper on survival and selected responses during the first larval stage (Zoea I). It thus offers a useful contribution to the knowledge of how this common stressor affects a conspicuous sub-Antarctic species.

\section{MATERIALS AND METHODS}

Larvae were obtained from ovigerous females collected in the Beagle Channel during the spring months, and kept in the laboratory until zoeae hatching. Larvae were maintained at a water temperature of $7.5 \pm 0.5^{\circ} \mathrm{C}$, a salinity of 28 and a photoperiod of 12L:12D (fluorescent light). Marine water used in the experiments was carried from open waters known as a pristine zone, filtered and UV-light lamp-treated prior to use. Metal stock solution, from which small aliquots were added to the dilution water, were prepared from analytical grade reagent $\mathrm{Cl}_{2} \mathrm{Cu}_{2}$ salt (Timper ${ }^{\circledR}, 99 \%$ purity), with no addition of acid. Test solutions and water control for each experiment were renewed daily. Only actively swimming larvae were selected for the assays and no food was given to the larvae during the experiments.

The 96-h $\mathrm{LC}_{50}$ and its $95 \%$ confidence limits were estimated using Probit analysis (Finney, 1971). The concentration series used (expressed in $\mu \mathrm{g} \mathrm{L}^{-1}$ ) was $160 ; 230 ; 350 ; 510 ; 740 ; 1100 ; 1160$. Groups of 10 organisms were placed in $150 \mathrm{~mL}$ of test solution. Each series was run in triplicate, including a water control. The cessation of movements was considered as the mortality criterion. Dead larvae were recorded daily and surviving animals were transferred to corresponding fresh test solution.

To analyse the effect on oxygen consumption and ammonia excretion, groups of 100 larvae each (divided into 4 subgroups of 25 individuals) hatched during the previous night were exposed for $96 \mathrm{~h}$ to 0 (control), 80 and $160 \mu \mathrm{g} \mathrm{L} \mathrm{L}^{-1}$ of copper. At the end of the exposure period each experimental test group was placed in 72-mL respirometer chambers, covered with dark paper to reduce the swimming activity, under a flow-through system $\left(12 \mathrm{ml} \mathrm{min}{ }^{-1}\right.$, by gravity). One chamber without organisms was added as a control. After a $2 \mathrm{~h}$ acclimation period, a water sample from each chamber was taken to determine the initial concentration of both oxygen (polarographic electrode YSI 5100) and ammonia (Strickland and Parsons, 1972). The flasks were sealed for $2 \mathrm{~h}$ and new samples were taken to measure the final concentrations. Consumed oxygen and excreted ammonia were calculated as the net difference between the initial and final value of the sealed period, corrected by the chamber capacity and dry weight of organisms in each one. The O:N ratio was estimated according to Taboada et al. (1998), using the individual values of oxygen consumption and ammonia excretion transformed to $\mu$ g-atom $\mathrm{g}^{-1} \mathrm{~h}^{-1}$.

To determine the effects on lipid peroxidation (LPO), larvae were exposed to 0 (control), 40, 80 and $160 \mu \mathrm{g} \mathrm{L}^{-1}$ for $96 \mathrm{~h}$ and daily subsamples of 50 larvae were taken in triplicate. LPO was determined according to Beuge and Aust (1972). Briefly, subsamples were homogenised in buffer Tris $0.1 \mathrm{M}$ $\mathrm{pH} 7.8$, with BHT added at a final concentration of $0.01 \% \mathrm{w} / \mathrm{v}$, and centrifuged. The supernatant 
was mixed with TCA-TBA-HCl solution $(15 \% \mathrm{w} / \mathrm{v}$ trichloroacetic acid, $0.375 \% \mathrm{w} / \mathrm{v}$ thiobarbituric acid, $0.25 \mathrm{~N}$ hydrochloric acid) and placed in a boiling water bath. The formation of thiobarbituric acid-reactive components in the reaction was determined at $535 \mathrm{~nm}$, using an extinction coefficient of $1.5610^{5}$ $\mathrm{M}^{-1} \mathrm{~cm}^{-1}$ to calculate malondialdehyde equivalents (MDA) expressed as $\mu \mathrm{M}$ MDA mg protein $^{-1}$. The protein content was measured according to Markwell et al. (1978) and the optical density was read at 750 $\mathrm{nm}$ in a spectrophotometer using bovine albumin as standard. All measurements were made in triplicate.

Body water content was determined in subsamples of 50 larvae in quadruplicate at 24 and $96 \mathrm{~h}$ of exposure for each treatment, dried at $60^{\circ} \mathrm{C}$ until constant weight.

\section{Statistical analysis}

Probit analysis (Finney, 1971) was employed to estimate the $\mathrm{LC}_{50}$ value and its $95 \%$ confidence limits, with Abbot's correction for mortality in controls. To compare $\mathrm{LC}_{50}$ values, differences were considered to be statistically significant when the higher $L C_{50}$ dlower $L C_{50}$ ratio exceeded the corresponding critical value established by the American Public Health Association et al. (1995).

To determine significant differences among treatments, normally distributed data were analyzed by one-way analysis of variance (ANOVA) and post hoc, least significant difference (LSD) range test (Sokal and Rohlf, 1981). Data not normally distributed were evaluated through the Kruskal-Wallis test and Dunn's multiple comparisons test (Daniel, 1978). In all statistical tests, results were considered significant when $p<0.05$. All statistical analyses were performed using STATISTICA (Statsoft).

\section{RESULTS}

No mortalities were recorded in the control group and no moulting was observed in either copper-exposed or control groups. The estimated $96-\mathrm{h} \mathrm{LC}_{50}$ was $298.5 \mu \mathrm{g} \mathrm{L}{ }^{-1}$. No significant differences $(p>0.05)$ between estimated 72 and $96 \mathrm{~h} \mathrm{LC}_{50}$ indicate an asymptotic trend in the acute toxicity and could be used as a threshold concentration (Table 1). Increased mortality was observed between 48 and $72 \mathrm{~h}$, particularly at the concentrations of 510 and $740 \mu \mathrm{g} \mathrm{L}{ }^{-1}$, reaching $100 \%$ mortality after $72 \mathrm{~h}$ of exposure (Fig. 1).
TABLE 1. - Parameters of acute lethal toxicity bioassays for Zoea I of Lithodes santolla exposed to copper. Same superscript letters indicate homogeneous group $(p>0.05)$

\begin{tabular}{ccccc}
\hline $\begin{array}{c}\text { Time of exposure } \\
(\mathrm{h})\end{array}$ & $\begin{array}{c}\mathrm{LC}_{50} \\
\left(\mu \mathrm{g} \mathrm{Cu} \mathrm{L}^{-1}\right)\end{array}$ & $\begin{array}{c}\text { Confidence limits } \\
(95 \%)\end{array}$ & Slope & $\mathrm{R}^{2}$ \\
\hline 24 & $1160.4^{\mathrm{a}}$ & $1071.5-1255.5$ & 11.25 & 0.95 \\
48 & $853.8^{\mathrm{b}}$ & $794.8-919.7$ & 13.77 & 0.99 \\
72 & $302.5^{\mathrm{c}}$ & $279.5-324.2$ & 15.33 & 0.99 \\
96 & $298.5^{\mathrm{c}}$ & $275.8-319.7$ & 16.09 & 0.99 \\
\hline
\end{tabular}

Oxygen consumption showed a non-significant increase in treatments (mean value $=52.62 \pm 5.32$ $\mu \mathrm{g}$-atom $\left.\mathrm{O}_{2} \mathrm{~h}^{-1} \mathrm{mg}^{-1}\right)$ in comparison with the control group $\left(45.27 \pm 6.76 \mu\right.$ g-atom $\left.\mathrm{O}_{2} \mathrm{~h}^{-1} \mathrm{mg}^{-1}\right)$ (Fig. 2a, ANOVA, $\left.F_{2: 10}=2.14, p=0.17\right)$. Ammonia excretion decreased significantly with increased copper concentration (Fig. 2 b, $F_{2.8}=4.89, p=0.04$ ), a $60 \%$ decrease was recorded between control and $160 \mu \mathrm{g}$ $\mathrm{L}^{-1}\left(1.61 \pm 0.65 \mu \mathrm{g}\right.$-atom $\mathrm{N}-\mathrm{NH}_{3} \mathrm{~h}^{-1} \mathrm{mg}^{-1}$ and 0.65 $\pm 0.08 \mu$ g-atom $\mathrm{N}-\mathrm{NH}_{3} \mathrm{~h}^{-1} \mathrm{mg}^{-1}$, respectively), so the $\mathrm{O}: \mathrm{N}$ atomic ratio increased significantly at the higher experimental copper concentration (O:N atomic ratio: $72.96 ; 117 \%$ higher than control), being homogeneous in the other tested groups (Fig. 2c, ANOVA, $F_{2 ; 9}=9.54, p=0.006$ ).

For each time of exposure, the trend of response of LPO in exposed organisms was to increase in comparison with the control group (Fig. 3). At the end of exposure MDA levels of organisms exposed to 80 and $160 \mu \mathrm{g} \mathrm{L}^{-1}$ treatments $(3.77 \pm 2.72$ and $4.27 \pm 2.25 \mu \mathrm{M}$ MDA mg protein $\left.{ }^{-1}\right)$ showed significant differences from the control group $(0.88 \pm 0.13$ $\mu \mathrm{M}$ MDA mg protein $\left.{ }^{-1}\right)$. In particular, the highest concentration assayed was always significantly different from the respective control (Kruskal-Wallis,

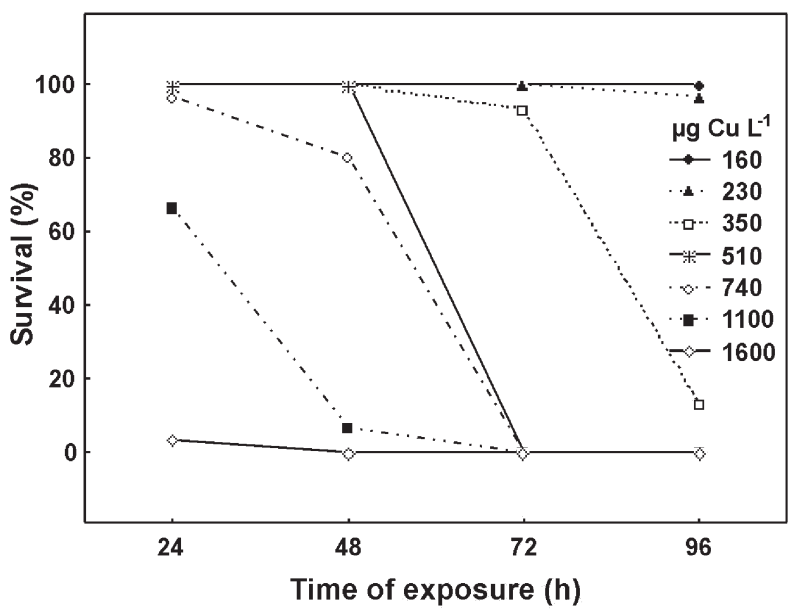

FIG. 1. - Survival (\%) of Zoea I of Lithodes santolla exposed to copper. 

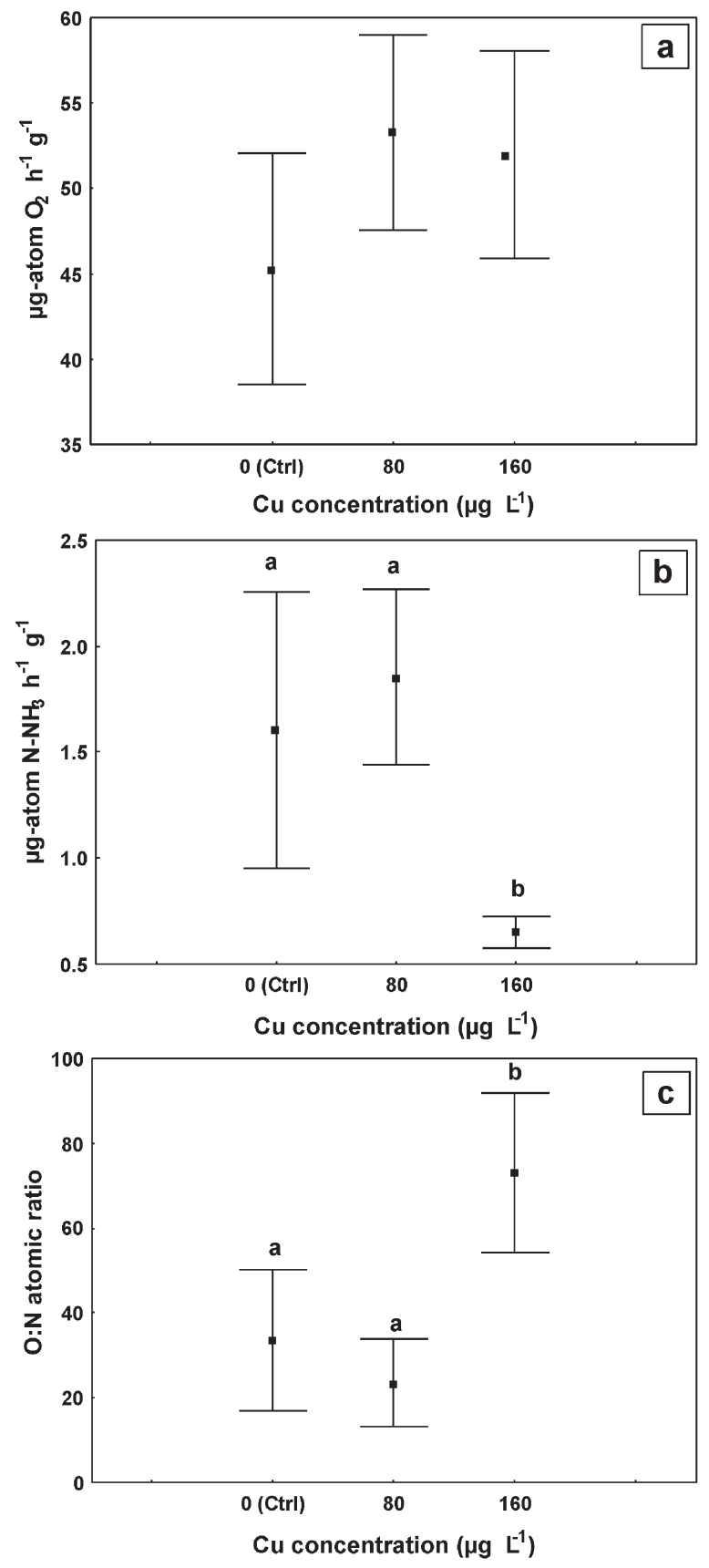

FIG. 2. - Oxygen consumption (a); ammonia excretion (b) and O:N atomic ratio (c) of Zoea I of Lithodes santolla exposed to copper. Mean \pm S.D. Treatments sharing the same letters are not significantly different (ANOVA, $p>0.05)$. $(0(\mathrm{Ctrl})=$ control group; 80 and 160 expressed as $\mu \mathrm{g} \mathrm{L}^{-1} ;$ S.D. $=$ standard deviation $)$.

$H_{24 h}=11.03, H_{48 h}=15.23, H_{72 h}=27.25, H_{96 h}=24.40$; $p \leq 0.01$ for all tests). Moreover, LPO for each treatment showed significant increases in a time-dependent way. This was evident in the lower concentration at 48-72 $\mathrm{h}$ and the higher concentrations at 72-96 h (Kruskal-Wallis, $H_{0.04}=10.93, H_{0.08}=14.89$, $H_{0.16}=25.48, p \leq 0.01$ for all tests).

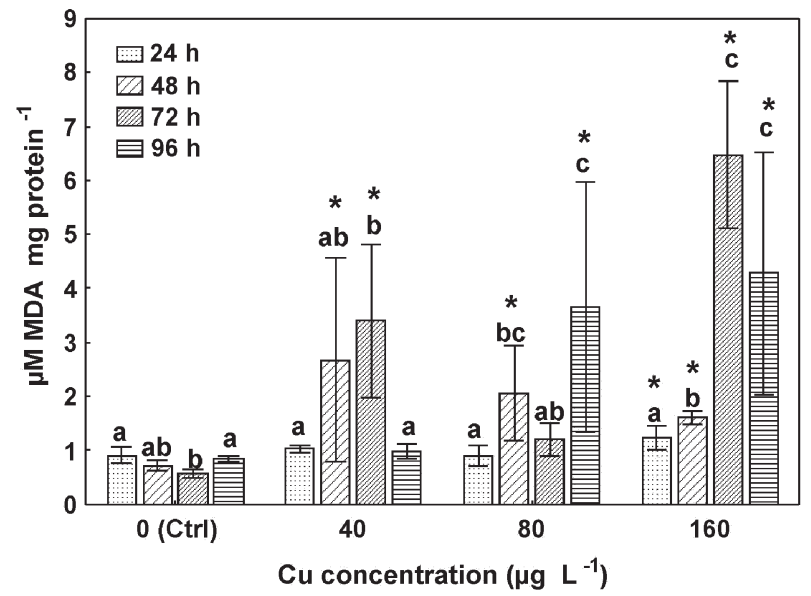

FIG. 3. - Lipid peroxidation of Zoea I of Lithodes santolla exposed to copper. Mean \pm S.D. Columns of each treatment sharing different letters are significantly different. Asterisks denote significant differences from the corresponding control (Kruskal-Wallis, $p<0.05$ ). (S.D. = standard deviation).

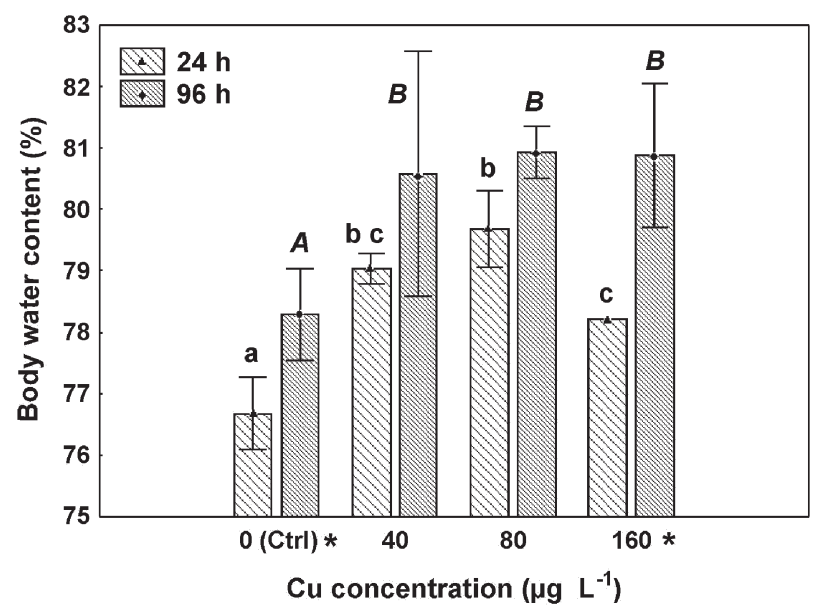

FIG. 4. - Body water content at 24 and $96 \mathrm{~h}$ of Zoea I of Lithodes santolla exposed to copper. Mean \pm S.D. Columns of each treatment and time sharing same letter are not significantly different (ANOVA, $p>0.05$ ). Asterisks denote significant differences among exposure time. $($ S.D. $=$ standard deviation $)$.

Regarding the exposure time, the body water content of treatments was significantly higher than the corresponding control group (Fig. 4, ANOVA, $F=18.6, p=0.004$ and $F=5.22, p=0.023$ for 24 and 96 $\mathrm{h}$ respectively). Similarly, for both the control and treatment groups a time-dependent response was observed, and was significant in the control and 160 $\mu \mathrm{g} \mathrm{\textrm {L } ^ { - 1 }}$ treatment.

\section{DISCUSSION}

Copper toxicity for $L$. santolla was in the same order of magnitude as in other crustacean larvae 
(Munshi et al., 1996; Ramachandran et al., 1997; Scelzo, 1997; López Greco et al., 2001; Ferrer et al., 2003). Copper was one order of magnitude more toxic than other metals assayed on the same species and larval stage, resulting in the following relative scale of acute lethal toxicity: $\mathrm{Cu}>\mathrm{Pb}>\mathrm{Cd}>\mathrm{Zn}$ (Amin et al., 2003). This tendency has also been observed in the local species Exosphaeroma gigas, in which copper was more toxic than $\mathrm{Cd}$ and $\mathrm{Zn}$ (Giarratano et al., 2007).

Oxygen consumption is considered to give a good indication of the overall metabolic state of an animal and is a useful indicator of sublethal physiological effects of heavy metal poisoning. Decreases in oxygen consumption have been attributed to ultrastructural damage to gill epithelium, while increases reflect an extra metabolic demand of the copper-exposed animals (Vosloo et al., 2001). In others cases, as Knops et al. (2001) also found, significant changes may not happen, although slight increases were detected in the present study. Knops et al. (2001) described three possible explanations for an unchanged metabolic rate under stress: the first is that the additional costs associated with stress are masked by other toxicant effects; the second is that this energy demand is too small compared with whole-metabolic costs, and the third is that at least during the exposure period there is no additional cost due to chemical stress.

On the other hand, the decrease in the ammonia excretion rate during copper exposure could be attributed either to decreased protein and amino acid catabolism or to an inability to clear ammonia excess from the body. The most consistent response to copper exposure is impaired ammonia excretion rather than the decrease in its production (Wilson and Taylor, 1993; Blanchard and Grosell, 2006); this could be an explanation for the present results, since no significant changes in oxygen consumption were detected.

As was established by Mayzaud and Conover (1988), a low O:N ratio corresponds to a period when protein is heavily used, while the highest values are closely related to the depletion of lipid reserves. Accordingly, in the present study the increase in $\mathrm{O}: \mathrm{N}$ ratio at the higher concentration was related to the decrease in ammonia excretion, rather than the utilisation of lipid reserves. As stated by Cheng et al. (2009), it is important to take into account that the $\mathrm{O}: \mathrm{N}$ ratio as a stress index requires additional measures related to metabolic effects. In fact, variation in $\mathrm{O}: \mathrm{N}$ ratio could be due to a change in one parameter or both parameters varying in a different proportion.

In molluscs and other crustacean species it has been shown that oxyradical production has a polluted-mediated mechanism of toxicity, and lipid peroxidation has been observed in individuals exposed to copper (Brouwner and Brouwner, 1998; Correia et al., 2002; Barata et al., 2005). Copper may act as a catalyst for the Fenton reaction, facilitating the conversion of superoxide anion and hydrogen peroxide to hydroxyradical, a species frequently proposed to initiate lipid peroxidation (Stohs and Bagchi, 1995). In particular, lipid peroxidation is considered to be the major mechanism by which oxyradicals can cause tissue damage, leading to impaired cellular function and alterations in physicochemical properties of cell membranes, which in turn disrupt vital functions (Rikans and Hornbrook, 1997). The observed increase in LPO may cause cellular injuries that possibly account for the observed decrease in ammonia excretion; however this needs to be evaluated further.

Water uptake is a natural mechanism which helps crustaceans in the moult process. In fact, previous studies established the mean duration of Lithodes santolla zoeae I as 5.2-5.5 days (Comoglio and Vinuesa, 1991; Amin et al., 2003), so increments in the body water content at $96 \mathrm{~h}$ observed in the present study could be related, in part, to this event. Furthermore, the main mode of toxic action of copper is regarded as affecting the membrane permeability (Ringwood et al., 1999; Viarengo et al., 2000). In accordance with these previous studies, our results have shown a relative water content increase in all treatments in comparison with the control group.

As has been demonstrated, the highest concentration employed in the physiological and biochemical studies $\left(160 \mu \mathrm{g} \mathrm{L}^{-1}\right)$, which represents about 50\% of estimated 96-h $\mathrm{LC}_{50}$, had evident effects on the analysed parameters. Furthermore, in addition to the information given previously, the values of copper in water reported for the coastal zone of Ushuaia bay (up to $60 \mu \mathrm{g} \mathrm{L}^{-1}$, Amin et al., 1997) exceed the one established by the United States Environmental Protection Agency (USEPA) (1999) for ambient water quality criteria. This reported value is also higher than those reported for other coastal zones of Argentina (i.e. $12 \mu \mathrm{g} \mathrm{L} \mathrm{L}^{-1}$ for Río de la Plata, Villar et al., 1999; and $4.65 \mu \mathrm{g} \mathrm{\textrm {L } ^ { - 1 }}$ for Bahía Blanca Estuary, Ferrer et al., 2003). It is therefore important to further the studies related to other aspects, such as 
moult, bioaccumulation and/or antioxidant defence responses of such a high heavy metal presence in the coastal zone of the Beagle Channel.

\section{ACKNOWLEDGEMENTS}

This study was supported by National Agency of Scientific and Technologic Promotion (ANPCyTPICTR2002/090 and PICT2006/01261), the National Research Council of Argentina (CONICET- PEI 6313) and PNUD 02/018 B-CB-05. Special thanks to Dirección de Recursos Naturales de Tierra del Fuego and Pesquera del Beagle S.A. for providing animals. We are grateful to Lic María Laura Borla for the final English revision. Thanks also to the anonymous reviewers for their valuable considerations.

\section{REFERENCES}

Amin, O.A., S. Andrade, L. Ferrer, L.I. Comoglio, J. Marcovecchio and N. San Román. - 1997. Use of macroalgae as bioindicator of heavy metals concentration in coastal zone of Beagle Channel, Tierra del Fuego, Argentina. Proc. Int. Symp. Cold Region Dev., 337-340.

Amin, O., E.M. Rodríguez, M. Hernando, L.I. Comoglio, L.S. López and D.A. Medesani. - 1998. Effects of lead and cadmium on hatching of the Southern King Crab Lithodes santolla (Decapoda, Anomura). Invertebr. Reprod. Dev., 33: 81-85.

Amin, O., L. Comoglio and E. Rodríguez. - 2003. Toxicity of Cadmium, Lead, and Zinc to larval stages of Lithodes santolla (Decapoda, Anomura). Bull. Environ. Contam. Toxicol., 71: 527-534.

American Public Health Association (APHA), American Water Works Association (AWWA) and Water Pollution Control Federation (WPCF). - 1995. Standard methods for the examination of water and wastewater. $19^{\text {th }}$ Edition APHA, Washington D.C.

Barata, C., I. Varo, J.C. Navarro, S. Arun and C. Porte. - 2005. Antioxidant enzyme activities and lipid peroxidation in the freshwater cladoceran Daphnia magna exposed to redox cycling compounds. Comp. Biochem. Physiol. C, 140: 175-186.

Beuge, J.A. and S.D. Aust. - 1972. Microsomal Lipoperoxidation. Methods Enzymol., 52: 302-307.

Blanchard, J. and M. Grosell. - 2006. Copper toxicity across salinities from freshwater to seawater in the euryhaline fish Fundulus heteroclitus: Is copper an ionoregulatory toxicant in high salinities?. Aquat. Toxicol., 80: 131-139.

Brouwner, M. and T.H. Brouwner. - 1998. Biochemical defense mechanisms against copper-induced oxidative damage in the blue crab, Callinectes sapidus. Arch. Biochem. Biophys., 351: 257-264.

Cheng, X.X., C.Y. Lu and Y. Ye. - 2009. Effect of Cd and Zn on oxygen consumption and ammonia excretion in sipuncula (Phascolosoma sculenta). Ecotoxicol. Environ. Saf., 72: 507-515.

Comoglio, L.I. and J.H. Vinuesa. - 1991. Larval culture under laboratory conditions of southern king crab Lithodes santolla and the false southern king crab Paralomis granulosa. Eur. Aquac. Soc., Special Publication 15: 349-351.

Correia, A.D., D.R. Livingstone and M.H. Costa. - 2002. Effects of water-born copper on metallothionein and lipid peroxidation in the marine amphipod Gammarus lacusta. Mar. Environ. Res., 54: $357-360$.

Daniel, W.W. - 1978. Applied nonparametric statistics. Ed. Houghton Mifflin Company, Boston.

Depledge, M.H. and P.S Rainbow. - 1990. Models of regulation and accumulation of trace metals in marine invertebrates. Comp. Biochem. Physiol. C, 97(1): 1-7.

Espina, S. and R.C. Vanegas Perez. - 2006. Ecotoxicología y Contaminación, In: A.V. Botello, J. Rendón-von Osten, G. GoldBouchot and C. Agraz-Hernández (eds.), Golfo de México, Contaminación e Impacto Ambiental: Diagnóstico y Tendencias. EPOMEX Serie Científica 5, pp. 79-120. Universidad Autónoma de México.

Ferrer, L.D., J.S. Andrade, E.T. Contardi, R.O. Asteasuaian and J.E. Marcovecchio. - 2003. Copper and zinc concentrations in Bahía Blanca Estuary (Argentina), and their acute lethal effects on larvae of the crab Chasmagnathus granulata. Chem. Speciat. Biovailab., 15: 7-14.

Fingerman, M., M. Devi, P.S. Reddy and R. Katyayani. - 1996. Impact of heavy metal exposure on the nervous system and endocrinemediated processes in crustaceans. Zool. Stud., 35: 1-8.

Finney, D.J. - 1971. Probit analysis. 3rd edition. Cambridge University Press, Cambridge.

Geracitano, L., J.M. Montserrat and A. Bianchini. - 2002. Physiological and antioxidant enzyme responses to acute and chronic exposure of Laeonereis acuta (Polychaeta, Nereididae) to copper. J. Exp. Mar. Biol. Ecol., 277: 145-156.

Giarratano, E., L. Comoglio and O.A. Amin. - 2007. Heavy metal toxicity in Exosphaeroma gigas (Crustacea, Isopoda) from the coastal zone of Beagle Channel. Ecotoxicol. Environ. Saf., 68(3): 451-462.

Knops, M., R. Altenburger and H. Segner. - 2001. Alterations of physiological energetics, growth and reproduction of Daphnia magna under toxicant stress. Aquat. Toxicol., 53: 79-90.

López Greco, L.S., M.V. Sánchez, G.L. Nicoloso, D.A. Medesani and E.M. Rodríguez. - 2001. Toxicity of cadmium and copper on larval and juvenile stages of the estuarine crab Chasmagnathus granulata (Brachyura, Grapsidae). Arch. Environ. Contam. Toxicol., 41: 333-338.

Lovrich, G.A. - 1997. La pesquería mixta de las centollas Lithodes santolla y Paralomis granulosa (Anomura: Lithodidae) en Tierra del Fuego, Argentina. Invest. Mar., 25: 41-57.

Marcovecchio, J.E. - 2000. Land-based sources and activities affecting the marine environment at the Upper Southwestern Atlantic Ocean: an overview. UNEP RSRS, 170: $67 \mathrm{pp}$.

Markwell, M.A.K., S.M. Hass, L.L. Bieber and N.E. Tolbert. 1978. A modification of the Lowry procedure to simplify protein determination in membrane and lipoprotein samples. Anal. Biochem., 87: 206-210.

Mayzaud, P. and R.J. Conover. - 1988. O:N atomic ratio as a tool to describe zooplankton metabolism. Mar. Ecol. Prog. Ser., 45: 289-302.

Munshi, A.B., S.Y. Quan and S.J. Li. - 1996. Acute toxicity of copper, cadmium and copper-cadmium mixture to the larvae of the shrimp Penaeus monodon. Pak. J. Sci. Res., 39: 68-71.

Newman, M.C. and M.G. Heagler. - 1991. Allometry of metal bioaccumulation and toxicity. In: M.C. Newman and A.W. McIntosh (eds.), Metal Ecotoxicology. Lewis, Boca Raton, FL, USA.

Ramachandran, S., T.R. Patel and M.H. Colbo. - 1997. Effect of copper and cadmium on three Malaysian tropical estuarine invertebrate larvae. Ecotoxicol. Environ. Saf., 36: 183-188.

Rikans, L.E. and K.R. Hornbrook. - 1997. Lipid peroxidation, antioxidant protection and aging. Biochim. Biophys Acta, 1362: $116-127$.

Ringwood, A.H., M.J. Hameedi, R.F. Lee, M. Brouwer, E.C. Peters, G.I. Scott, S.N. Luoma, R.T. DiGiulio. - 1999. Bivalve Biomarker Workshop: overview and discussion group summaries. Biomarkers, 4: 391-399.

Scelzo, M.A. - 1997. Toxicidad del cobre en larvas nauplii del camarón comercial Artemesia longinaris Bate (Crustacea, Decapoda, Penaeidae). Invest. Mar., 25: 177-185.

Soegianto, A., M. Charmantier-Daures, J.P. Trilles and G. Charmantier. - 1999. Impact of cadmium on the structure of gills and epipodites of the shrimp Penaeus japonicus (Crustacea: Decapoda). Aquat. Living Resour., 12(1): 57-70.

Sokal, R.R. and F.J. Rohlf. - 1981. Biometry. W.H. Freeman and Company, New York, USA.

Stohs, S.J. and D. Bagchi. - 1995. Oxidative mechanisms in the toxicity of metal ions. Free Radic. Biol. Med., 18(2): 321-336.

Strickland, J.D.H. and T.R. Parsons. - 1972. A practical handbook of seawater analysis. Bull. Fish Res. Board Can., Bulletin 167, $2^{\text {nd }}$ ed. 
Taboada, G., G. Gaxiola, T. García, R. Pedroza, A. Sanchez, L.A Soto and C. Rosas. 1998. Oxygen consupmtion and ammonia $\mathrm{N}$-excretion related to protein requirements for growth of white shrimp, Penaeus vannammei (L.), juveniles. Aquac. Res., 29: 822-833.

United Sates Environmental Protection Agency. - 1999. National Recommended Water Quality Criteria-Correction. Office of Water Epa 822-Z-99-001

Viarengo, A., M. Lafaurie, G.P. Gabrielides, R. Fabbri, A. Marro and M. Romeo. - 2000. Critical evaluation of an intercalibration exercise undertaken in the framework of the MED POL. biomonitoring program. Mar. Environ. Res., 49: 1-18.

Villar, C, J. Stripeikis, M. Tudino, L. d'Huicque, O. Troccoli and C. Bonetto. - 1999. Trace metal concentrations in coastal marshes of the lower Paraná River and the Río de la Plata estuary. Hydrobiol., 397: 187-195.
Vosloo, A., W.J. Van Aardt and L.J. Mienie. - 2002. Sublethal effects of copper on the freshwater crab Potamonautes warreni. Comp. Biochem. Physiol. A, 133: 695-702.

Wilson, R.W. and E.W. Taylor. - 1993. Differential responses to copper in Rainbow Trout (Oncorhynchus mykiss) acclimated to seawater and brackish water. J. Comp. Physiol. B, 163: 239-246.

Zapata, V., L. López Greco and E. Rodríguez. - 2001. Effect of copper on hatching and development of larvae of the estuarine crab Chasmagnathus granulata (Decapoda, Brachyura). Environ. Toxicol. Chem., 20(7): 1579-1583.

Scient. ed.: C. Porte.

Received January 7, 2009. Accepted May 15, 2009.

Published online February 22, 2010. 